\title{
Paideusis
}

\section{A Rejoinder to Kraevskii}

\section{Attila Horvath}

Volume 3, Number 1, 1989

URI: https://id.erudit.org/iderudit/1073403ar

DOI: https://doi.org/10.7202/1073403ar

See table of contents

Publisher(s)

Canadian Philosophy of Education Society

ISSN

0838-4517 (print)

1916-0348 (digital)

Explore this journal

Cite this article

Horvath, A. (1989). A Rejoinder to Kraevskii. Paideusis, 3(1), 4-4.

https://doi.org/10.7202/1073403ar

This document is protected by copyright law. Use of the services of Erudit (including reproduction) is subject to its terms and conditions, which can be viewed online.

https://apropos.erudit.org/en/users/policy-on-use/
This article is disseminated and preserved by Érudit.

Érudit is a non-profit inter-university consortium of the Université de Montréal, Université Laval, and the Université du Québec à Montréal. Its mission is to promote and disseminate research.

https://www.erudit.org/en/ 


\section{A Rejoinder to Kraevskii}

\section{Attila Horvath, Budapest Institute of Pedagogy}

I was very happy to meet Professor Kraevskii at the Pecs Conference in the summer of 1988. I had hoped to hear news about the "difficult, but inspiring, process of re-evaluating the whole system" as promised in his response. But what $I$ heard at the conference and read in his reply is foreign to me. Unfortunately, it is still not clear to me exactly what perestroika means. I hear the words and see the sentences all of which make sense in themselves but, when I put them together, they seem as elusive as the old rhetoric. Sometimes I have the impression that glasnost and perestroika are the Potomkin props of the play.

The more we hear the word perestroika, the more we feel at home with with the concept. Sometimes I feel that I know what it means. I sense a warm, positive feeling when I hear the word. I even cheer for its foremost representatives. But was does it mean in reality. Is it really the fundamental reevaluation of the system? If yes, does it mean--as it does in Hungary--that communism must be given up? Openness, freedom of expression, and creativity requires the abolition of Bolshevism and its uncompromising unity in views. Moreover, it means the acceptance of traditional Western values, something that no true communist can afford. If there are fundamental values which are shared with the bourgeoisie, then there cannot be the antagonistic dichotomy between communism and capitalism. So I wonder how communists in the Soviet Union imagine the set of "universally shared values" about which Kraevskii writes. My point was that there are no such common points in the Soviet-type Marxism and analytical philosophy. East European systems were based on the total negation of capitalism. A password, like perestroika, cannot conceal this background. A facelift given to Leninism does not change the fundamental character of communism. Perestroika is still communism. The paradigm has not changed. This is not to say that things cannot improve under communism. Certainly, the situation could be much worse. But how much should we be impressed?

I wish that Kraevskii had mentioned one single concrete thing that perestroika could be credited with. Had he done this, we could have seen whether this "re-evaluation" follows communist values or tends to favour Western values. One might claim that things are not so black-and-white. I say that they are. I am afraid that many Eastern European Marxists would like to see "democratization" (Kraevskii's word) instead of democracy and would like to give "the feeling of freedom of choice" (his words again), instead of providing freedom of choice simpliciter.

I certainly agree that we all should build a humanist society where personality is the highest social value, where differentiation and individualization are of paramount importance, and where encouraging self-government is a key value. I wish my Soviet friends strength and success in achieving these aims. But, then, Professor Kraevskii, what shall we do with communism? 